\title{
Laryngeal Osteoma: A Rare Cause of Laryngeal Obstruction
}

\author{
Laringeal Osteom: Laringeal Obstrüksiyonun Nadir Bir Nedeni
}

\author{
Ahmet Rifat KARASALIHOĞLU ${ }^{1}$, Abdullah TAŞ ${ }^{1}$, Recep YAĞIZ ${ }^{1}$, Ömer YALÇIN ${ }^{2}$, Muhsin KOTEN ${ }^{1}$, Murat KOÇYİĞITT \\ ${ }^{1}$ Trakya Üniversitesi Tıp Fakültesi, Kulak Burun Boğaz Anabilim Dal, , ${ }^{2}$ Patoloji Anabilim Dall, Edirne
}

Submitted / Başvuru tarihi: 25.09.2008 Accepted / Kabul tarihi: 14.11.2008

\begin{abstract}
Osteomas are benign, typically slow-growing tumors composed of densely sclerotic, well circumscribed bone. Laryngeal osteomas are extremely rare. We report an extremely rare case of laryngeal osteoma. The patient had complaints ofdysphonia for 3 years and, dyspnea for 1 month. There was a supraglottic mass filling the laryngeal lumen on indirect laryngoscopic examination. Mass was completely excised using microlaryngoscopic instruments. After the operation, the patient's complaints were completely resolved. Case reports and a review of the world literature concerning laryngeal osteoma and treatment are presented.
\end{abstract}

Key words: Laryngeal neoplasm; osteoma; dyspnea.
Osteomlar selim, tipik olarak yavaş büyüyen, belirgin sınırlı, yoğun siklerotik kemik tümörleridir. Laringeal osteom çok enderdir. Biz bu çalışmamızda çok ender görülen laringeal osteomlu bir olgu sunuyoruz. Olgunun 3 yıldır ses kısıklığı ve 1 aydır nefes darlığı şikayeti vardı. Indirekt larinks muayenesinde, laringeal boşluğu dolduran supraglottik kitle vardı. Kitle mikrolaringoskopik aletler kullanılarak tam olarak çıkarıldı. Operasyon sonrası hastanın şikayetleri tam olarak geriledi. Laringeal osteomlu olgu tedavisi ile literatür eşliğinde sunulmuştur. Anahtar sözcükler: Laringeal neoplasm; osteom; dispne.

\section{INTRODUCTION}

Osteomas are usually located in the skull and facial bones, and they are the most common benign tumor of the sinonasal tract. ${ }^{[1]}$ Osteomas are benign, typically slow-growing tumors composed of densely sclerotic, well circumscribed bone. Laryngeal osteoma is an extremely rare entity. ${ }^{[2]}$ To our knowledge, only two cases of laryngeal osteoma have been previously reported in the English literature. ${ }^{[1,2]}$ Osteomas are rockhard, irregularly nodular or granular masses of bone. Histologically, wide trabeculae of mature bone array in an irregular pattern. ${ }^{[1]}$ Histologically, three types of osteoma are recognized: compact, cancellous and mixed. [3] Radiographically, osteomas appear as well-defined calcified masses. Computed tomography (CT) can help define the extent of an osteoma and assist with surgical planning for excision. ${ }^{[2]}$ In this article, we presented a case with laryngeal osteoma whose complaints were similar to obstructive laryngeal malignity.

\section{CASE REPORT}

An 87 year-old-man was referred to our clinic with severe dyspnea, dysphonia and dysphagia. He had complained of dysphonia for 3 years and dyspnea for 1 month. There was a supraglottic mass filling the laryngeal lumen on indirect laryngoscopic examination. We performed tracheotomy urgently from second tracheal ring. The endoscopic examination of the larynx revealed a mass in the larynx that was extending from the inferior border of the epiglottis to the left vocal fold and partially occupying the left side of the supraglottic compartment (Fig. 1A). The left vocal fold could not be visualised due to the mass. The mass had a firm, smooth surface and was not ulcerous. There was no palpable lymphadenomegaly in the neck. CT of the larynx was performed, 
showing a osteomatous mass involving the supraglottic region (Fig. 1B). On operative microlaryngoscopy, a firm calcified mass was encountered in the supraglottic region. The mass was completely excised using microlaryngoscopic instruments. After the operation, the patient's complaints were completely resolved. Decanulation was performed the day after the operation. The histopathological examination showed that the mass, composed of bone and soft tissue, was $2.5 \times 2.2 \mathrm{~cm}$ in size. The cut surface showed a solid, firm and white noduler mass (Fig. 2). Microscopically, there was benign osseous tumor in the tissue covered by squamous epithelium. It was composed of lamellar, thick bone spiculae joined to each other, containing loose and scanty bone marrow. The bone spiculae had geographical mineralization and rare osteoblasts (Fig. 3). Postoperatively, the endoscopic examination of the larynx was normal (Fig. 4). He has been well without any sign or symptoms for eight months.

\section{DISCUSSION}

Osteomas are most commonly found in the frontal sinus; the ethmoid sinus and maxillar sinus follow respectivelly. Paranasal sinus osteoma incidence was 3\%, with a predilection for decades 5-6 and a male-to- female ratio of $1.3-1 .^{[4]}$ The etiology of osteoma is unknown. There are a number of theories on the pathogenesis of osteomas. Accepted theories point to embryologic, traumatic and infectious causes. ${ }^{[3]}$ Osteomas arising from laryngeal cartilages are extremely rare. Chondrosarcoma and chondroma rarely occur in the larynx. Thyroid cartilage osteoma, which causes difficult endotracheal intubation, has been reported. ${ }^{[5]}$ Laryngeal osteoma was first reported in 2000 by Batti and Abromson. ${ }^{[1]}$ In this case, the osteoma was located in the cricoid cartilage and was excised endoscopically. In our case, the osteoma was located anterior to the larynx in a supraglottic location and its diameter was $2 \mathrm{~cm}$. Mehta et al. ${ }^{[2]}$ reported the second case of laryngeal osteoma. Their case had a history of long periods of intubations. He had progressive dyspnea and dysphonia. Osteoma was located in the interarytenoid region. In our case, there was no intubation or infection history. The posterolateral portion of the cricoid cartilage is the most common site $(70 \%)$ for cartilaginous neoplasms of the larynx and
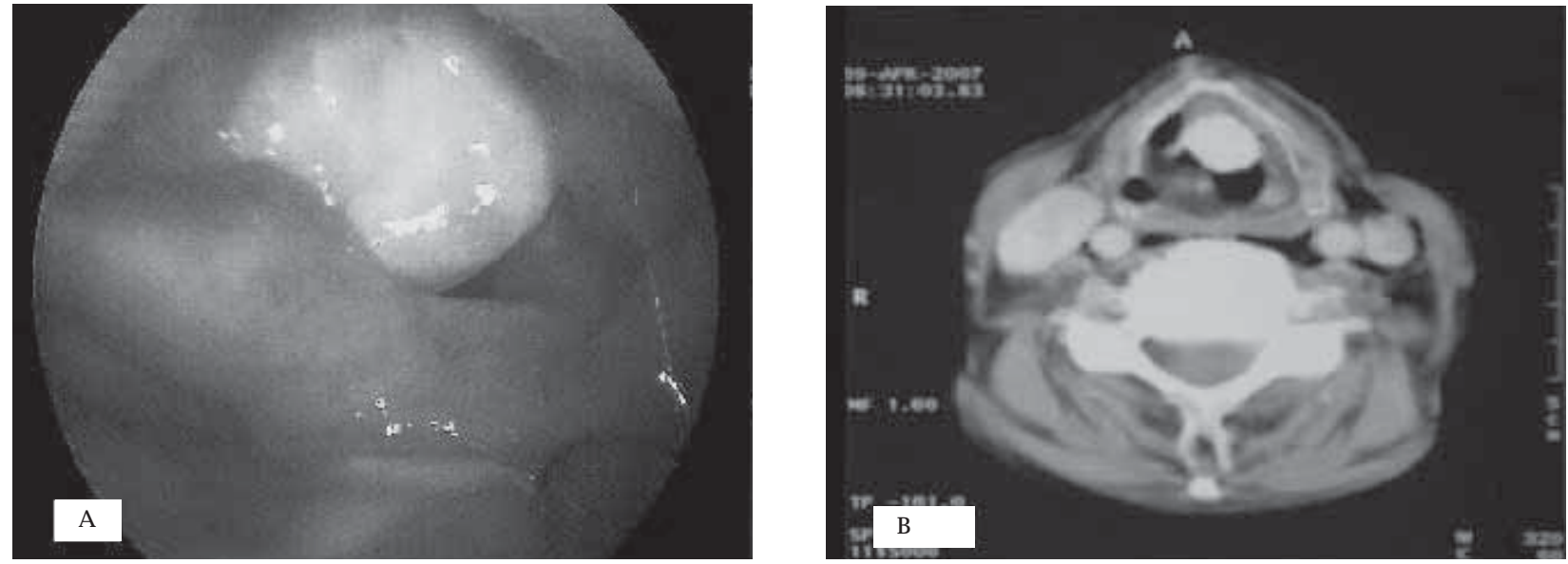

Figure 1. Endoscopic appearance of the larynx before treatment $(A)$ and CT showing a osteomatous mass involving the supraglottic region $(B)$
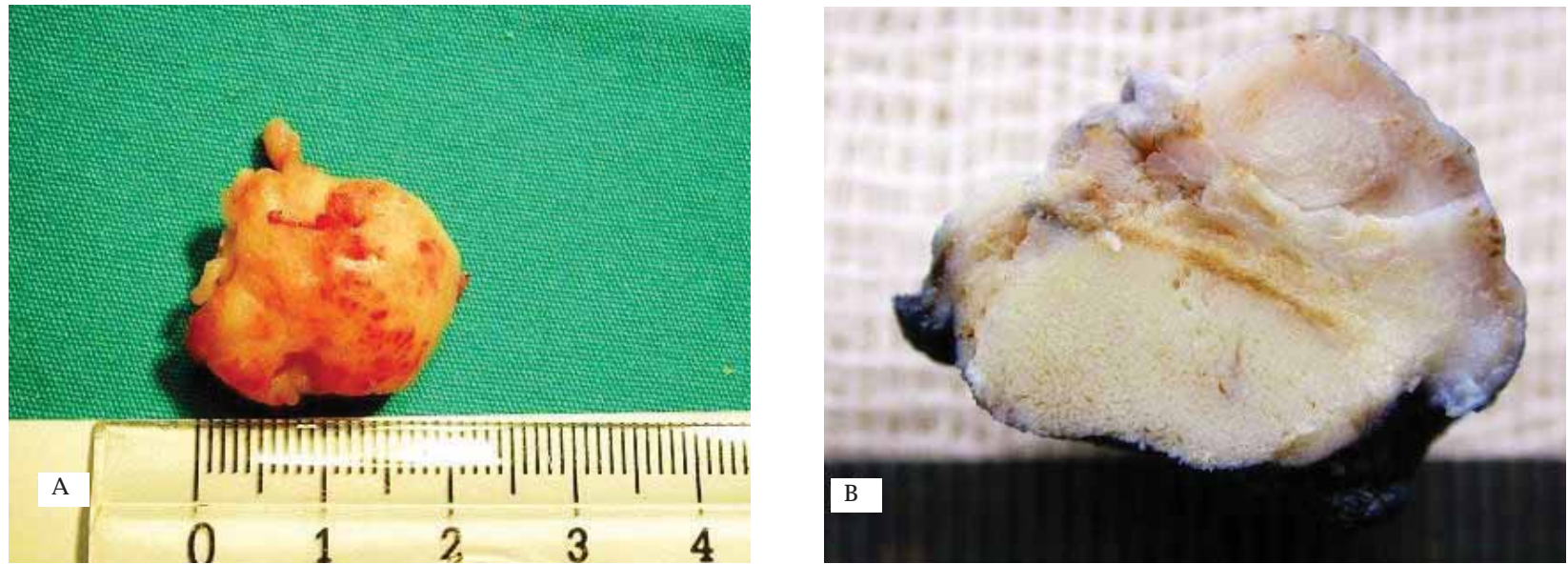

Figure 2. Macroscopic appearance of the tumor, postoperatively (A) and the cut surface of the tumor (B). 


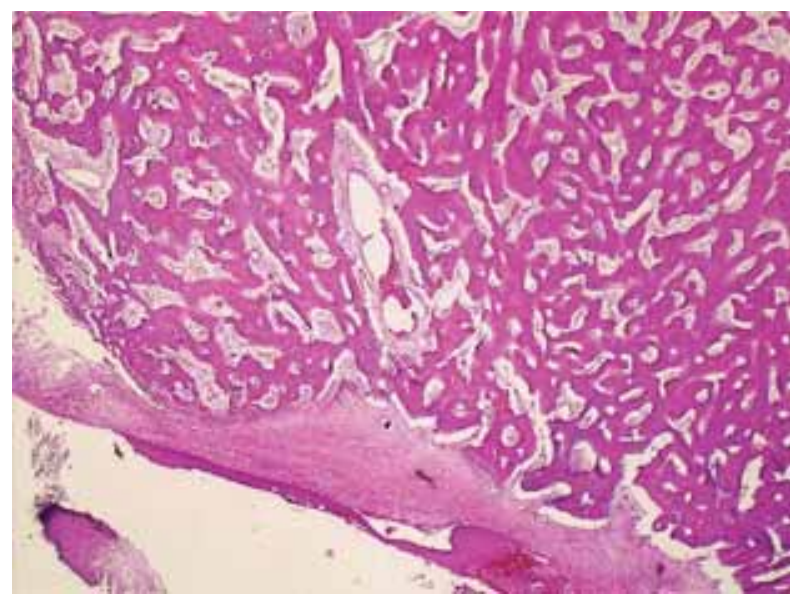

Figure 3. The tumor composed of lamellar and thick bone spiculae joining each other. HEE X 12.

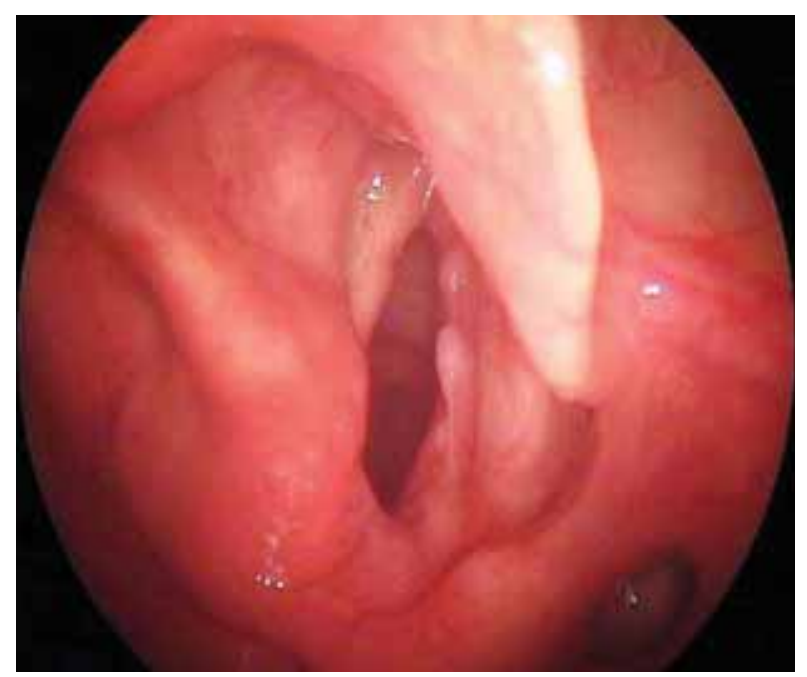

Figure 4. Endoscopic appereance of the larynx, postoperatively. thyroid cartilage $(20 \%)$ and the body of arytenoids $(10 \%)$ follow it. ${ }^{[1]}$ Differential diagnosis of osteoma includes ossifying fibroma, osteoblastoma, osteosarcoma and chondrosarcomatous osteosarcoma. ${ }^{[1,2]}$ In the presence of multiple osteomas, the diagnosis of Gardner's syndrome should be considered. Gardner's syndrome is an autosomal dominant disease that is characterized by multiple osteomas, polyps in the upper and lower gastrointestinal tract, and skin and soft tissue tumors such as epidermoid cyst and desmoid tumors. It is critical to identify the gastrointestinal tract polyps because they have a high risk of malignant transformation..$^{[1,2]}$ In our case, there iwas no evidence of Gardner's syndrome. Surgical excision is generally regarded as the mainstay of treatment for symptomatic osteomas. During the excision of any benign laryngeal lesion, the main goal is to preserve laryngeal function. Recurrence after excision of osteomas is uncommon, but there are insufficient cases of the larynx osteoma in the literature.

In conclusion, osteomas of the larynx are extremely rare but can cause laryngeal obstruction. Surgical excision is the principal treatment for this rare lesion.

\section{Conflict of Interest}

No conflict of interest declared by the authors.

\section{REFERENCES}

1. Batti JS, Abramson A. First report of a case of osteoma of the larynx. Ear Nose Throat J 2000;79:564-8.

2. Mehta RP, Faquin WC, Franco RA. Pathology quiz case1. Arch Otolaryngol Head Neck Surg 2006;132:1390-2.

3. Wanyura H, Kaminski A, Stopa Z. Treatment of osteomas located between the anterior cranial base and the face. J Craniomaxillofac Surg 2005;33:267-75.

4. Earwaker J. Paranasal sinus osteomas:a review of 46 cases. Skeletal Radiol 1993;22:417-23.

5. Redman AGO, Hide IG, Zammit-Maempel I. Osteoma of the thyroid cartilage- an unusual cause of difficult intubation. Br J Radiol 2000;73:899-900. 